\title{
Counterfeit Medicines in Socioeconomic Perspective
}

\author{
Obat-obatan Palsu dalam Perspektif Sosial Ekonomi
}

\section{Desy Nuryunarsih}

\author{
College of Human Medicine, Division Public Health, Michigan State University, East Lansing, Michigan, The \\ United States of America
}

\begin{abstract}
Counterfeit medicines potentially reach $70 \%$ of the global drug markets, and the largest proportion is found in developing countries. Increasing public awareness of counterfeit medicines will automatically affect the demand for counterfeit medical products that will finally reduce counterfeit medicine activities. However, raising awareness of the dangers of counterfeit medicines is a challenging task because public health professionals need to consider diversity of social, economic and educational factors. This study examined peer-reviewed journal articles, media reports, official government and non-government reports. As many as 179 papers (1990 to 2014) were retrieved to identify the relationship between Human Development Index (HDI) of the USA, Japan, Brazil, Iran, Vietnam, Indonesia, Pakistan and Nigeria, and the type of counterfeit medicines. An electronic search was conducted using the following databases, such as Medline, Scopus, CINAHL, Embase, Google Scholar. Counterfeit disease curing medicines are found in high varieties most likely in countries with low HDI. At the same time, medicines for lifestyle are not solely found in countries with high HDI, but also exist in low to medium HDI.

Keywords: Counterfeit medicines, disease curing medicine, human development index, lifestyle of drug use, public health

\section{Abstrak}

Obat-obatan palsu berpotensi mencapai $70 \%$ dari pasaran obat internasional dengan proporsi terbanyak ditemukan di negara berkembang. Meningkatkan kesadaran masyarakat akan adanya obat-obatan palsu akan secara langsung memengaruhi permintaan produk obat palsu yang akhirnya akan mengurangi kegiatan pemalsuan obat. Akan tetapi, meningkatkan pengetahuan masyarakat akan bahaya obat-obatan palsu tidaklah mudah sebab profesi kesehatan masyarakat harus juga mempertimbangkan keberagaman faktor-faktor sosial, ekonomi dan pendidikan. Laporan ini menelaah artikel jurnal yang ditelaah oleh kelompok seminat, laporan media, laporan resmi pemerintah dan non-pemerintah. Sebanyak 179 artikel (dari 1990 sampai 2014) ditelaah untuk mengetahui hubungan antara indeks pembangunan manusia (IPM) dari USA, Jepang, Brasil, Iran, Vietnam, Indonesia, Pakistan dan Nigeria, dan tipe pemalsuan obat. Pencarian elektronik menggunakan pangkalan data seperti Medline, Scopus, CINAHL, Embase, Google Scholar. Obat-obatan palsu untuk pengobatan ditemukan dalam banyak ragam terutama di negara dengan IPM rendah. Pada saat yang sama, obat-obatan untuk keperluan gaya hidup tidak hanya ditemukan di negara dengan IPM tinggi, akan tetapi juga beredar di negara dengan IPM rendah dan sedang.

Kata kunci: Obat palsu, pengobatan penyakit, indeks pembangunan manusia, gaya hidup penggunaan obat, kesehatan masyarakat
\end{abstract}

How to Cite: Nuryunarsih D. Counterfeit Medicines in Socioeconomic Perspective. Kesmas: National Public Health Journal. 2017; 11 (4): 153162. (doi:10.21109/kesmas.v11i4.1440)
Correspondence: Desy Nuryunarsih, College of Human Medicine, Division Public Health, Michigan State University, Broughton Drive Nottingham United Kingdom NG8 1DW, Phone: -, e-mail: nuryunar@msu.edu Received: February $11^{\text {th }} 2017$

Revised: April 18 th 2017

Accepted: April 26th 2017 


\section{Introduction}

Counterfeit medicine is on the rise globally and an emerging issue in both developing and developed countries. However, the true extent of the problem is not really known because no global study has been conducted. ${ }^{1}$ The World Health Organization (WHO) estimates that $6 \%$ of worldwide pharmaceutical sales are counterfeit and that up to $70 \%$ of all medicines sold in several developing countries are counterfeit. ${ }^{1}$ The government authorities and medicine manufacturers have made extensive attempts to fight drug counterfeiting, but old and new counterfeiters have used several methods to escape detection. ${ }^{2}$

Many types of medicines have been counterfeited, including antibiotics, hormones, analgesics, steroids, antihistamines, vitamins, malaria medicines, flu medicines, and HIV/AIDS medicines. ${ }^{3,4}$ However, the exact amount of counterfeit medicine is unknown, and little reliable data are available for both developed and developing countries. In some developing countries, the problem of data gathering is made more difficult due to a lack of agreement on the definition of counterfeit medicine and these countries are often reluctant to make information on counterfeit medicine public. 3,5

Countries with low socioeconomic factor are more vulnerable to widespread counterfeit medicines due to the high price of the medications. ${ }^{6}$ People in developing countries must choose between low price counterfeit medicines or not buying any medicine. Drugs that are frequently counterfeited in developing countries are medicines that are used to treat life-threatening diseases, such as malaria, tuberculosis, HIV/AIDS, and other serious infectious conditions. ${ }^{7}$ In contrary, counterfeit lifestyle medicines are most likely to be found in developed countries. ${ }^{8,9}$ In developed countries, counterfeiters aim for high demand or costly products, such as medicines used to treat erectile dysfunction, hypercholesterolemia, hypertension and cancer. ${ }^{10,11}$ Thus, it is unclear whether counterfeit medicine is prevalent in the countries that have a low per capita income and low education level, or if counterfeit medicines are increasing in developed countries because counterfeiters target high demand and resale value.

To address the counterfeit medicine problem, WHO has developed a definition that a counterfeit medicine is a medicine which is fraudulently and deliberately mislabeled with respect to identity and/or source. Counterfeiting can apply to both branded and generic products, and counterfeit products may include products with the correct ingredients or with the wrong ingredients, without active ingredients, with insufficient active ingredients or with fake packaging. ${ }^{1,12}$ Every medicine counterfeiting activity has significant repercussions for society, potentially threatening public health because con- sumption of counterfeit medicines may lead to death or ineffective treatment.

According to Spink, ${ }^{13}$ and Moyer, ${ }^{14}$ from Michigan State University, there are seven types of fraud and counterfeiting incidents and their potential harm to public health. The first type is adulteration, in which the counterfeiter adds more ingredients with the intention of forging components of the products. The result is a product that is impure, that has lost the active ingredient, or that is given at an improper dose. The second type is tampering, in which the counterfeiter obtains the original product and packaging, but with the intent to fraudulently use them. For example, the counterfeiter may change the expiration date or product labelling. This may lead to the death of the consumer. The third type is overrun, in which the counterfeiter outside of the quantity makes legitimate medicines in a production agreement. These activities are dangerous because the product will be distributed outside the regulated or controlled supply chain. The fourth type is theft, in which the counterfeiter steals legitimate products and sells them as legitimate products. Similar to overrun, legitimate products will be distributed outside the regulated or controlled supply chain. The fifth type is diversion, which is also known as a parallel trade, the grey market or product arbitrage. This type of fraud may result in a lack of legitimate products in the market, causing a delay in a patient getting the medicine. Another type is simulation, in which the counterfeiter copies the legitimate product but does not use the same ingredients. This will affect patient safety, as the resulting medicine is fake or of a lower quality. The last type is counterfeiting, where the counterfeiter copies exactly the same drug as the legitimate product with the intention to mislead the patient. The product and packaging of the legal medicines are fully replicated, which causes the patient to consume a product that is evidently impure.

Combating counterfeiting/fraud activities requires a strong commitment from the governments and authorities around the world. ${ }^{15}$ Knowledge of the reasons why counterfeiters falsify medicines is also very important. The medicine product supply chain is controlled by the government under the law; however, people can help to decrease the demand for counterfeit medicines by purchasing medicines from authorised pharmacies. 16

Economic factors are one of main reasons for counterfeiting medicines. However, other motivations also exist, such as part of terrorist activities or for other criminal motives. ${ }^{15,17}$ Socioeconomic factors contribute to counterfeiting activities in many countries. A prior study has investigated aspects of the relationship between socioeconomic variables and counterfeit medicine. ${ }^{18}$ However, indicators of socioeconomic status, such as education, income, and culture are independent variables. 
For example, people that have the same level of formal education could have different perspectives on health due to different cultural backgrounds. ${ }^{19,20}$ These perspectives at times lead to incorrect conclusions about the relationship between socioeconomic indicators and health outcomes or health perspectives in general. The aim of this study was to determine whether or not the type of medicines (medicine for lifestyle or disease treatment) related to the socioeconomic factors based on the human development index (HDI) in eight selected countries of the world.

\section{Method}

\section{Identification of Studies}

This search strategy and term were utilised a systematic review style an approach which is considered a legitimate study methodology. ${ }^{21}$ To identify and highlight the primary study studies and to determine the relationship between HDI and type of medicines being counterfeited in Eight selected countries, four major electronic databases such as Medline, Scopus, CINAHL, EMBASE, Google Scholars were used. The keywords included 'counterfeiting', 'counterfeit medicines', 'substandard drugs', 'fake drugs', 'world counterfeiting', and 'counterfeit medicines' as well as 'counterfeit drugs/medicines/medicines' in eight selected countries that are the USA, Japan, Brazil, Iran, Indonesia, Vietnam, Nigeria and Pakistan. Extracted data about counterfeit medicines were analyzed using a table that categorized counterfeit medicines based on their labelling package type medicines. The medicines were then grouped into two broad classes, namely lifestyle drugs and disease curing medicine classes.

\section{Inclusion Criteria}

Records that reported on the prevalence and potential public health and socioeconomic concern of counterfeit medicines in developed and developing countries were selected using preferred reporting items for systematic reviews and Meta-Analysis (PRISMA) guideline procedure (Figure 1). The title and abstracts of the identified articles were checked against predetermined criteria for eligibility of the study that deal with various aspects of counterfeit medicines for lifestyle and disease treatment and relevant to the study objectives. The most informative version of the study was included in multiple publication that presented identical data. A study published in Indonesian language was then translated, and relevant papers were included. The full text of all selected studies was obtained and assessed. Of 179 potential articles identified by these criteria, 58 studies were included for eligibility. Lastly, remaining ten records was included in the narrative synthesis. The selected countries were selected based on the HDI with very high HDI in USA and Japan, high HDI in Brazil and Iran, medium HDI in Indonesia and Vietnam, and low HDI in Nigeria and

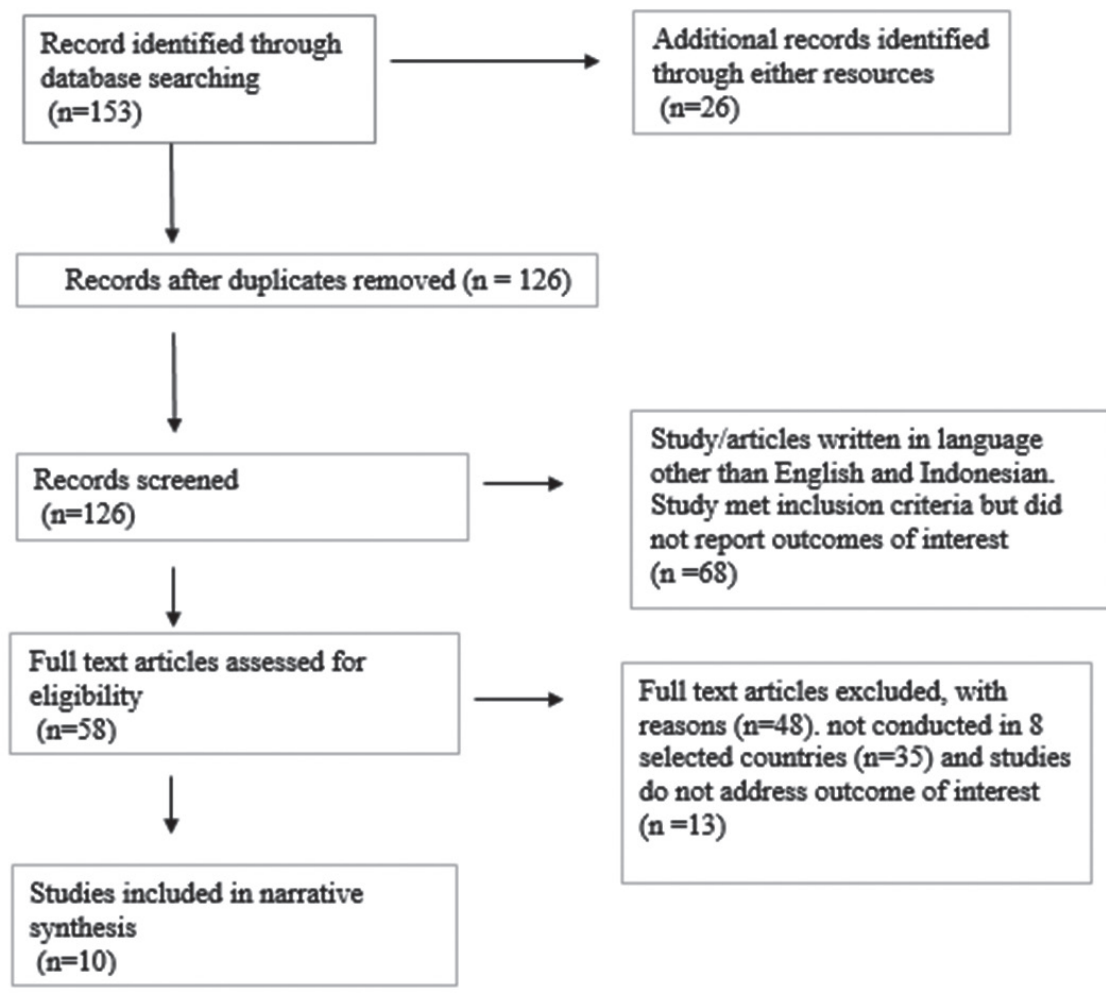

Figure 1. PRISMA Flow Diagram Showing the Exclusion and Inclusion of Studies for Analysis 
Table 1. Units of Analysis from Peer-Reviewed Journals

\begin{tabular}{|c|c|c|c|c|}
\hline Author & Sampling Technique/Sample & Purpose & Study Design & Findings \\
\hline Beverly D Glass $^{9}$ & Not specified & $\begin{array}{l}\text { To review on counterfeit medicines } \\
\text { and medical devices in developing } \\
\text { countries. }\end{array}$ & Not specified & $\begin{array}{l}\text { Primarily expensive medicines for lifestyle such as } \\
\text { sildenafil and tadalafil are counterfeited in the } \\
\text { developed world, while those drugs frequent } \\
\text { ly counterfeited in developing countries are to } \\
\text { treat life-threatening diseases such as malaria, } \\
\text { tuberculosis, HIV/AIDS, and other serious } \\
\text { infectious disease. }\end{array}$ \\
\hline IMPACT,23 & $\begin{array}{l}110 \text { samples medicines from } \\
6 \text { countries (China, Indonesia, } \\
\text { Laos, Myanmar, Thailand, } \\
\text { Vietnam) }\end{array}$ & $\begin{array}{l}\text { To investigate the medicine market } \\
\text { surveillance in the six participating } \\
\text { countries }\end{array}$ & $\begin{array}{l}\text { Cross-sectional } \\
\text { study }\end{array}$ & $\begin{array}{l}\text { Counterfeit anti-malarial accounted } 6 \% \text { of all } \\
\text { samples, erectile dysfunction medicines comprised } \\
16 \% \text { of samples, antibiotic, antipsychotics an } \\
\text { tiplatelet made up } 18 \% \text { of the samples. } \\
\text { Vietnam: Vietnamese police were able to detect and } \\
\text { seize } 8 \text { cases of counterfeit medicines in } 2008 \text { com } \\
\text { prised of } 14,000 \text { Viagra tablets, } 170 \text { Cialis blister, } \\
1022 \text { Augmentin, } 75 \text { Levista boxes, } 106 \text { Rovanten, } \\
200 \text { Vinka, } 43 \text { Amoxicillin. Both life-threatening } \\
\text { and lifestyle medicines were found in China, } \\
\text { Indonesia, Vietnam, Thailand, Laos and Myanmar. }\end{array}$ \\
\hline Hosseini SA et al. ${ }^{24}$ & $\begin{array}{l}\text { Simple random sampling } \\
(n=716) \text { of counterfeit medicines }\end{array}$ & $\begin{array}{l}\text { To gain insight into the medicine grey } \\
\text { market in Iran. Define the counterfeit } \\
\text { medicine pattern in Iran }\end{array}$ & $\begin{array}{l}\text { Cross-sectional } \\
\text { retrospective } \\
\text { study. }\end{array}$ & $\begin{array}{l}\text { Of the } 716 \text { bogus medicines: } 64.5 \% \text { were } \\
\text { supplement } 10.2 \% \text { were analgesic, } 7.8 \% \text { were } \\
\text { hormones, } 3.2 \% \text { were antihistamines, } 2-4 \% \\
\text { unknown, } 1-2 \% \text { cardiovascular disease medicine, } \\
\text { diabetes medicines, genitourinary system, } \\
\text { gastrointestinal system. }\end{array}$ \\
\hline Ames J 25 & Not mentioned & $\begin{array}{l}\text { To identify the main counterfeit seized } \\
\text { by the Brazilian federal police and the } \\
\text { states where seizure have been made. }\end{array}$ & $\begin{array}{l}\text { Retrospective } \\
\text { descriptive study }\end{array}$ & $\begin{array}{l}\text { The medicine with greatest numbers of seizure } \\
\text { were selective phosphodiesterase five inhibitors } \\
\text { that are used for treatment male erectile } \\
\text { dysfunction; Cialis, Viagra; mean }=66 \% \text {. Followed } \\
\text { by anabolic steroids (durateston and hemogenin) } \\
8.9 \% \text { and } 5.7 \% \text {. }\end{array}$ \\
\hline $\mathrm{JPMA}^{26}$ & $\begin{array}{l}\mathrm{n}=88.543 \\
\text { number of seizures of imported } \\
\text { IP infringing medicines cases } \\
\text { seized }\end{array}$ & $\begin{array}{l}\text { To Understand the current activities } \\
\text { concerning counterfeit medicines and } \\
\text { the level of impact on member } \\
\text { companies of the JPMA, and to } \\
\text { prepare plans for the further strategies } \\
\text { combating counterfeited drugs }\end{array}$ & $\begin{array}{l}\text { Cross-sectional } \\
\text { internet survey to } \\
53 \text { member } \\
\text { companies of JPMA }\end{array}$ & $\begin{array}{l}\text { Most medicine counterfeit medicines were drugs } \\
\text { for the improvement of sexual performance. } \\
\text { Total cases found in Japan domestic capital } \\
\text { companies; Number of cases: } \\
\text { Antibiotic (22), antiviral drugs (5), drugs for } \\
\text { improvement sexual performance }(1,643) \text {, oral } \\
\text { contraceptives (38), Alopecia drugs (6), anti- } \\
\text { obesity (2), anticancer (59), antipsychotic drugs } \\
\text { (6), anti-depressant (4), Dementia drugs (6), } \\
\text { anti-depressant (4), anti-hypertensives (14), lipid } \\
\text { lowering drugs (22), external preparations (21), } \\
\text { atopic dermatitis drugs (2), anti-diabetic drugs } \\
\text { (59), anti-inflammatory analgesic (66), other (92). }\end{array}$ \\
\hline Pfizer 27 & $\begin{array}{l}n=600.000 \text { Sample of } \\
\text { counterfeited drugs }\end{array}$ & $\begin{array}{l}\text { To remind of fake medicines which had } \\
\text { spread to } 15 \text { US states }\end{array}$ & Case study & $\begin{array}{l}18 \text { million counterfeits Lipitor were seized. } \\
\text { Fake Lipitor was found in } 15 \text { USA states and } \\
\text { was suspected in a further six states. }\end{array}$ \\
\hline
\end{tabular}

\section{Notes:}

IMPACT = International Medical Product Anti-Counterfeiting Taskforce

JPMA = Japan Medicine Manufacturers Association

Pakistan. ${ }^{22}$

\section{Exclusion Criteria}

At first, a total of 179 articles were identified through searching various database (153 articles) and other sources ( 26 articles). However, 53 articles were rejected because of repetition and resultant 126 articles were chosen. In the screening phase, 68 studies were excluded as they reported in language other than English and Indonesian, and did not report outcomes of interest. Subsequently, in the eligibility phase, 48 articles were eliminated as they were not included into cases in eight selected countries (USA, Japan, Brazil, Iran, Indonesia, Vietnam, Pakistan, Nigeria).

\section{Results}

A review of the 153 published and 26 additional records between 1990 to 2014 was conducted on the type of counterfeit medicines in relation with socioeconomic factors based on eight selected HDI countries. The review of the literature included peer-reviewed journal articles, media reports, government and non-government reports. 
Table 2. Units of Analysis from Official Website Drug Agencies, Media Report and Press Release on Counterfeit Medicines

\begin{tabular}{|c|c|c|}
\hline Country & Findings & Website \\
\hline USA28 & $\begin{array}{l}\text { Counterfeit medicines in the USA from } 2002 \text { to 2008; Diet pills, cancer medicines, } \\
\text { growth medicines, male sexual enchanter, flu medicines, counterfeit medical } \\
\text { devices, Botox. }\end{array}$ & U.S Food and Drug Administration. \\
\hline Pakistan $29-33$ & $\begin{array}{l}\text { Counterfeit medicines found in Pakistan from } 2002 \text { to } 2008 \text {; Fake herbal medicines, } \\
\text { Dengue fever medicines, antibiotic, anti-tuberculosis medicines, anti-malarial } \\
\text { medicines, heart medicines, cancer medicines. }\end{array}$ & $\begin{array}{l}\text { WHO, several media report and press release: the } \\
\text { news.com, samaa.tv, tribune.com, the nation.com, } \\
\text { safemedicines.org, radionz. }\end{array}$ \\
\hline Vietnam 34 & Anti-malarial, antibiotic, anti-tuberculosis, antiretroviral medicines & $\begin{array}{l}\text { The State of Medicine Quality in the Mekong } \\
\text { sub-region }\end{array}$ \\
\hline Indonesia 35 & $\begin{array}{l}\text { Total cases of counterfeit medicines from } 2001 \text { to } 2008 \text { in Indonesia were } 162 \text { cases. } \\
\text { Most counterfeit medicines were Antibiotic. } \\
\text { Total cases found: Antibiotic (39), antiviral drugs ( } 7) \text {, drugs for improvement sexual } \\
\text { performance (9), contraceptive (3), anti-obesity (2), anti-depressant (8), anti- } \\
\text { hypertensive (5), lipid lowering drugs (4), atopic dermatitis drugs (2), anti-diabetic } \\
\text { drugs (13), vaccine (3), anti-allergy (14), drugs for improvement sexual } \\
\text { performance (9), antifungal (11), others (7). }\end{array}$ & National Agency Drug and Food Control (BPOM) \\
\hline
\end{tabular}

There were 58 relevant peer-reviewed journal articles identified, and six were based on five selected countries setting (Table 1). Additionally, there were four reports from government and media about counterfeit medicine cases from three different selected countries (Table 2 and Table 3).

The general outlook comparison between counterfeit lifestyle medicines for and disease treatment in selected countries based on HDI year 1990 to 2014 is presented in Figure 2. From the graph, the number of counterfeit lifestyle medicine is very high with 16 types in the very high HDI countries followed by high and medium HDI with nine types of counterfeit lifestyle, then low HDI countries with medicines for five counterfeit lifestyle medicines for.

On the other hand, the number of counterfeit medicines for disease treatment in low HDI had the highest types as many as fourteen, followed by medium HDI with twelve types, then high HDI with nine types, and the last was very high HDI with five types of counterfeit medicines for treatment.

\section{Discussion}

Measuring socioeconomic status in practice is not simple. SES has many indicators that describe the individual's access to social and economic resources. Among the most common, used indicators are education, occupation, income, wealth, and years of school completed. 36

The HDI was utilized in this study as it is the most common value in representing the SES level in general. The Human Development Index (HDI) reflects the positive association between income on one side and health and education on the other. Thus, it offers a powerful alternative to income as a summary measure of human well-being.

The food and drug administration (FDA) announced the trafficking of fraudulent, counterfeit, and substan- dard medicines, supplements, and medical devices from several countries to the USA, including high demand lifestyle medicines such as Botox and expensive medicines such as cancer medicines. ${ }^{37}$

The FDA proactively responds to trafficking of counterfeit medicines. Public awareness has increased sharply, however, counterfeit medicines persist. If counterfeit medicines can enter the legal supply chain in the USA, the counterfeit medicine can most likely enter the markets of other countries. 37

The cases of counterfeit medicines in selected countries with very HDI selected countries are higher than others, more likely because of efficient counterfeiting cases report file and well-organized anti-counterfeiting agency. 15

In countries with very high HDI, despite a well-protected supply chain, medicine quality control and good social and physical security, counterfeit medicines still can be found. People living in developed countries such as Japan are exposed to fake medicines via illegal websites in which unauthorized websites are difficult to monitor and can easily escape the notice of authorities. Japan is a country with a $\$ 96.5$ billion expenditure in medicine, almost twice as much as Latin American medicine sales. 38 in 2010, there were 490 cases of counterfeit medicine in Japan, increasing approximately 7.3\% from 2011. Lifestyle medicines (Viagra and Cialis) were the major medicine counterfeiting products.

This study found that most counterfeited medicines in very high HDI were lifestyle medicines for. In developed countries, counterfeiter generally targets high-volume, high-cost drugs. This mean that the medicines potentially targeted were lifestyle medicines. However, the data in Table 2 also suggest that list has been expanded to nearly every kind of medicines, particularly those in high demand like antiviral, anticancer medicines, etc. 39

In 2012, the Brazilian authorities established 13-digit 
Table 3. Counterfeit Medicines in Eight Selected Countries Based on Types of Medicine Being Counterfeited

\begin{tabular}{|c|c|c|c|c|c|}
\hline Country & $\begin{array}{l}\text { Counterfeit Medicine- } \\
\text { Labelling Package }\end{array}$ & $\begin{array}{l}\text { Type of Medicine Being } \\
\text { Counterfeited }\end{array}$ & Country & $\begin{array}{l}\text { Counterfeit Medicine- } \\
\text { Labelling Package }\end{array}$ & $\begin{array}{l}\text { Type of Medicine Being } \\
\text { Counterfeited }\end{array}$ \\
\hline \multirow[t]{9}{*}{ USA } & Diet pills & Lifestyle drugs & Indonesia & Diet pills & Lifestyle medicines \\
\hline & Growth medicines & Lifestyle medicines & & Anti-depressant & Lifestyle medicines \\
\hline & Medicines for improvement of & Lifestyle medicines & & Anti-inflammation & Disease curing medicines \\
\hline & sexual performance & & & Anti-diabetic & Lifestyle medicines \\
\hline & Flu medicines & Lifestyle medicines & & Anti-fungi & Disease curing medicines \\
\hline & Botox & Lifestyle medicines & & Cough medicines & Disease curing medicines \\
\hline & Anti-psychotic & Lifestyle medicines & & Lipid lowering medicines & Lifestyle medicines \\
\hline & Cancer medicines & Disease curing medicines & & Anti-hypertension & Disease curing medicines \\
\hline & Anabolic steroid & Lifestyle medicines & & Gastrointestinal medicines & Disease curing medicines \\
\hline \multirow[t]{13}{*}{ Japan } & $\begin{array}{l}\text { Medicines for the improvement of } \\
\text { sexual performance }\end{array}$ & Lifestyle medicines & & $\begin{array}{l}\text { medicines for the improvement of } \\
\text { sexual performance }\end{array}$ & Lifestyle medicines \\
\hline & Oral contraceptive & Lifestyle medicines & & Malaria medicines & Disease curing medicines \\
\hline & Anti-depressant & Lifestyle medicines & & Analgesic & Disease curing medicines \\
\hline & Anti-psychotic & Lifestyle medicines & & Cardiovascular medicines & Disease curing medicines \\
\hline & Malaria medicines & Disease curing medicines & & Vitamin & Lifestyle medicines \\
\hline & Alopecia medicines & Lifestyle medicines & & Contraceptive oral & Lifestyle medicines \\
\hline & Anti-obesity & Lifestyle medicines & Vietnam & Medicines for the improvement of & Lifestyle medicines \\
\hline & Dementia medicines & Lifestyle medicines & & sexual performance & \\
\hline & Lipid lowering medicines & Disease curing medicines & & Antibiotic & Disease curing medicines \\
\hline & Atopic dermatitis & Lifestyle medicines & & Vitamins & Lifestyle medicines \\
\hline & Antidiabetic & Lifestyle medicines & & Malaria medicines & Disease curing medicines \\
\hline & Anti-inflammatory & Disease curing medicines & & Anti-retroviral medicines & Disease curing medicines \\
\hline & Analgesic & Disease curing medicines & & Anti-tuberculosis & Disease curing medicines \\
\hline \multirow[t]{5}{*}{ Brazil } & Medicines for improvement of & Lifestyle medicines & Pakistan & Dengue fever medicines & Disease curing medicines \\
\hline & sexual performance & & & Antibiotic & Disease curing medicines \\
\hline & Anabolic steroid & Lifestyle medicines & & Anti-tuberculosis drug & Disease curing medicines \\
\hline & Contraceptive & Lifestyle medicines & & Anti-malarial & Disease curing medicines \\
\hline & Cancer medicines & Disease curing medicines & & & Disease curing medicines \\
\hline \multirow[t]{16}{*}{ Iran } & Supplement & Lifestyle medicines & & Heart medicines & Disease curing medicines \\
\hline & Analgesic & Disease curing medicines & & Cancer medicines & Disease curing medicines \\
\hline & Hormones & Lifestyle medicines & & Medicines for the improvement of & Lifestyle medicines \\
\hline & Anti-histamine & Disease curing medicines & & sexual performance & \\
\hline & Cardiovascular disease medicines & Disease curing medicines & Nigeria & Analgesic & Disease curing medicines \\
\hline & Anti-Diabetes & Lifestyle medicines & & Anti-diabetic & Lifestyle medicines \\
\hline & Genitourinary system medicines & Disease curing medicines & & Cancer medicines & Disease curing medicines \\
\hline & Gastrointestinal system medicines & Disease curing medicines & & Muscle relaxant & Disease curing medicines \\
\hline & Eye \& Eye Nose Throat & Disease curing medicines & & Anti-epileptic & Disease curing medicines \\
\hline & Musculoskeletal system & Disease curing medicines & & Immune thrombocytopenia & Disease curing medicines \\
\hline & Anti-histamine & Disease curing medicines & & Antibiotic & Disease curing medicines \\
\hline & Central Nervous system & Disease curing medicines & & Mucolytic & Disease curing medicines \\
\hline & Herbals & Lifestyle medicines & & Diet pills & Lifestyle medicines \\
\hline & Dermatologists & Lifestyle medicines & & Vitamins & Lifestyle medicines \\
\hline & Psychotropic & Lifestyle medicines & & Malaria medicines & Disease curing medicines \\
\hline & & & & Anti-anxiety medicines & Lifestyle medicines \\
\hline
\end{tabular}

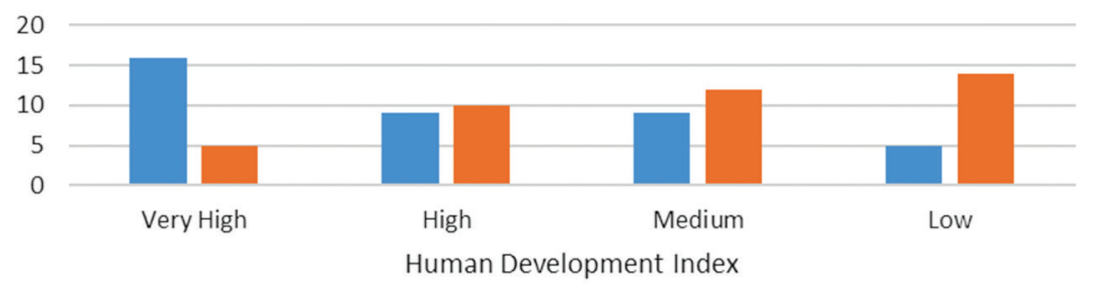

- Lifestyle drugs Medicines

Figure 2. Comparison between Counterfeit Medicine for Lifestyle and Disease Treatment in Year 1990-2014 Selected Countries Based on HDI

unique drug identifiers for securing the medicine products. Lifestyle medicines for are aimed at indications where treatment is largely a matter of patient choice and not a medical requirement. Patients consider embarrass- ing products such as erectile dysfunction, obesity, and those products are usually expensive as an apparent economic incentive to counterfeiter. 40

Unofficial and official reports about counterfeit - 
medicine have increased recently in Iran. From 2007 to 2008 , there were 716 cases of counterfeit medicines, and $64.5 \%$ were potentially harmful supplements. ${ }^{24}$ Iran's geographical location is very important because of its central location in Eurasia and Western Asia. However, Iran's political situation results in a breakdown of international trade.

In Vietnam, medicines for lifestyle such as sex enchantment medicines were most prevalent while counterfeit antibiotic such as anti-malarial medicines were also well-publicized cases. ${ }^{41}$ Indonesia and nine other countries have participated in all five Operation Storm campaigns as well as in Operation Pangea, which targets online medicine sales. According to the National Agency of Drug and Food Control of the Republic of Indonesia (NADFC/Badan Pengawas Obat dan Makanan), 268, 219, 266, and 146 cases of counterfeit medicine were found in 2003 to 2006, respectively. ${ }^{35}$ NADFC established many ways to combat counterfeiters, including encouraging the medicine industry to collaborate with the government to eradicate counterfeit medicines, participating in Operation Storm, and raising public awareness of the dangers of counterfeit medicines.

In low socioeconomic countries, it is often hard to prove a causative link between counterfeit medicines and illness or death because limited clinical autopsies and toxicology report that explained the cause of death. ${ }^{42}$ There is one market where price is more important than quality. The poorest consumers in Africa are forced to choose between low-quality medicines that are inexpensive or not purchasing the medicines at all. The ultimate solution to this dilemma is for the government to ensure that medicines for disease treatment are affordable for all. ${ }^{7}$

The main factors underlying the problem of counterfeit medicines in developing countries are the weak drug regulatory control, enforcement, scarcity and/or erratic supply of basic medicine, uncontrolled distribution chains, large price differentials between genuine and counterfeit medicines, lack of effective Intellectual Property Right (IPR) protection, lack of regard for quality assurance and corruption of the health care system. ${ }^{43}$

Trends in counterfeit medicine vary depending on many factors, such as the strength of the rule of law and rural versus urban settings. These factors vary even within countries. Health professionals play a major role in helping medicines that reach patients without endangering patients' health. ${ }^{44}$

In Nigeria, by 2001 , more than $40 \%$ of medicines in circulation were fake. ${ }^{45,46}$ Most counterfeit medicine supplies $(75 \%)$ were imported from China and India.4,47 People living in Nigeria are thus impacted by the dangerous effects of the counterfeit medicine. In 2008, 64\% of anti-malarial medicines were either counterfeit or sub- standard. ${ }^{18}$ It is noted that low dose artesunate does not kill malaria parasite but anchorages the emerge of artesunate-resistant strains.

Several counterfeit medicines seized in Nigeria are heart medicines, cancer medicines, antibiotic, analgesic and anti-malarial. These products include medicines for lifestyleas well as for disease treatment.

Similar to Nigeria, imports of counterfeit medicines in Pakistan have also increased in recent years, along with the increase of Pakistan's local production and supply of medicines. Meanwhile, the WHO estimated that as many as 40 to $50 \%$ of needed medicines are substandard or counterfeit medicine. ${ }^{33}$ Counterfeit medicines are rampant in both rural and urban areas. Counterfeit versions of life-saving prescription medicines for cancer and serious cardiovascular diseases were being sold to costumers in Pakistan, meanwhile counterfeit antibiotic, analgesic and antipyretic also well-noted. 43,44

In accordance with the law of supply and demand, as the price of medicines rises, poor people will search for medicines at low prices, and this leads to the vulnerability of the people who are forced to choose to buy substandard or counterfeit medicines from the illegal market. Some illegal medicines in Iran are imported from India and China. Most counterfeit medicines products seized are supplements, hormone medicines, and analgesic and antihistamine medicines. 24,48

\section{Conclusion}

This review of articles shows that counterfeit medicines are available in USA, Japan, Iran, Brazil, Indonesia, Vietnam, Pakistan and Nigeria. Counterfeit medicines can enter strong drug regulatory authorities such as in USA and Japan as people living in these countries are most likely exposed to counterfeit medicines via the internet.

In very high and high development indexed countries, expensive medicines for lifestyle (e.g. sildenafil, Cialis) as well as expensive high demand medicines are counterfeited. Meanwhile, in countries with medium and low development index countries, medicines to treat life-threatening diseases such as malaria, tuberculosis and other serious conditions are counterfeited. Counterfeit medicines pos a serious threat to the public health as medicine are purposively to reduce mortality and morbidity, counterfeit medicines are extremely harmful to health and safety of patients. Furthermore, combating the counterfeit medicines problem is important to ensure patients not to lose faith in the benefits of medicines.

\section{Recommendation}

Counterfeit medicines pose an increase threat to people as well as to individuals; direct harm to policy making and social prosperity budget. People worldwide should 
understand about the harm of counterfeit medicines and stop purchasing counterfeit medicines. The only way to combat this lucrative fraudulent criminal is by decreasing their sales.

Improving quality of medicines, increase the availability of inexpensive essential medicines, as well as strengthening medicine regulatory authority is a very important task for developing world to combat the counterfeiter.

At the national level, sustained political and economic supports from the government to coordinate police, scientist, medicine industries as well as enforcement the laws and regulations on counterfeit medicines is crucial to combat counterfeit medicines.

Meanwhile, at the international level, drug registration should be strengthened to ensure that all imported as well as local medicines industries produce high quality medicines before placing them to the market. To tackle the counterfeiter, there is also a need for continuous cooperation between the government of developed and developing countries and WHO.

Due to the expansion of the counterfeit medicines through the internet, cooperation amongst policy makers, brand owners, entrepreneurs, marketers, and other stakeholders is a key to controlling the availability and supply of the counterfeit medicines from the internet.

\section{Acknowledgment}

I would like to thank Kusuma Yudhopranoto, MD from the University of Diponegoro Indonesia who provided insight into this project.

\section{References}

1. World Health Organization. WHO I Growing threat from counterfeit medicines. Bulletin WHO. 2011 [cited September 2016] ; 88 (10): 1-3. Available from: http://www.who.int/bulletin/volumes/88/4/10020410/en/.

2. World Health Organization. WHO launces taskforce to fight counterfeit drugs. Bulletin WHO. 2006 [cited September 2016]; 84 (9): 1-8. Available from: http://www.who.int/bulletin/volumes/84/9/news.pdf

3. World Health Organization. Report of the situation of counterfeit medicines based on data collection tool. WHO Regions for Africa and Eastern Mediterranean. A World Health Organization Resource. 2010 [cited September 2016). Available from: http://apps.who.int/medicinedocs/en/d/Js18385en/. Published 2010.

4. Raufu A. India agrees to help Nigeria tackle the import of fake drugs. British Medical Journal. 2003 [cited November 2016]; 326 (7401). Available from: http://www.bmj.com/content/326/7401/1234.4.

5. Clift C. Combating counterfeit, falsified and substandard medicines: defining the way forward? I Chatham House. Briefing paper. Center of Global Security United Kingdom. 2010 [Cited November 2016]:6. Available from: https://www.chathamhouse.org/publications/papers/ view/109517.

6. World Health Organization. Affordable medicines for developing coun- tries : pills and pocket book. Geneva: World Health Organization; 2000 [cited September 2016]. Available from : http://www.who.int/medicines/areas/access/OMS_Medicine_prices.pdf.

7. Akunyili D. Lessons from Nigeria?: the fight against counterfeit drugs in Africa. Diabetes Society Journal. 2006 [cited September 2016]; 51 (3): 41-55. Available from: http://apps.who.int/medicinedocs/documents/s18404en/s18404en.pdf

8. Amin AA, Kokwaro GO. Antimalarial drug quality in Africa. Journal Clinical Pharmacology Therapy. 2007 [cited September 2016]; 32 (5): 429-40. Available from: https://www.ncbi. nlm.nih.gov/pmc/articles/ PMC2653781/

9. Glass BD. Counterfeit drugs and medical devices in developing countries: Study report. Tropical medicine Journal. 2014 [cited October 2016]; 5: 11-22. Available from : http://studyonline.jcu.edu.au/33198/

10. Pullirsch D, Bellemare J, Hackl A, Trottier YL, Mayrhofer A, Schindl H, et al. Microbiological contamination in counterfeit and unapproved drugs. British Medical Pharmacology and Toxicology Journal. 2014 [cited November 2017]; 15: 34. Available from : https://www.ncbi.nlm. nih.gov/pubmed/24965483.

11. US Food and Drug Administration. Counterfeit drugs: fighting illegal supply chains. US Food and Drugs Administration. 2014 [cited September 2016]. Available from: https://www.fda.gov/newsevents/testimony/ ucm387449.htm. Published 2014.

12.Wold Health Organizations. WHO launches taskforce to fight counterfeit drugs. Bulletin World Health Organization. 2011 [cited December 2016]; 84(9): 2-7. Available from: http://www.who.int/bulletin/volumes/84/9/06-010906/en/.

13. Spink J, Moyer D. Understanding food and combating fraud. Food Technology Magazine USA. 2013 [cited September 2016]; 67: 30-35. Available from: http://foodfraud.msu.edu/wp-content/uploads/2013/03/Article-Understanding-and-Combating-Food-Fraud-FTFood-Technology-2013-01-b.pdf.

14. Moyer D, Spink J. Defining public health threat of food fraud. Food science Journal. 2011 [cited September 2016]; 76: 157-63. Available from: https://www.ncbi.nlm.nih.gov/pubmed/22416717

15. Davidson M. Medicine Anti-counterfeiting: Government issue. London: John Wiley and sons Ltd; 2011.

16. Laeny R. Anjuran dari Kemenkes agar terhindar obat palsu I Republika Online. Republika [cited September 2016]. Available from : http://nasional.republika.co.id/berita/nasional/umum/14/11/27/nfpbyl-anjurandari-kemenkes-agar-terhindar-obat-palsu.

17. Spink J. Product fraud and product counterfeiting as a source of terrorist financing. Security Journal. 2015 [cited November 2016]; 19: 72. Available from : http://foodfraud.msu.edu/2015/02/27/publicationproduct-fraud-and-product-counterfeiting-as-a-source-of-terrorist-financing/

18. Blackstone EA, Fuhr JP, Pociask S. The health and economic effects of counterfeit drugs. American Healing drug benefits journal. 2014 [cited October 2016]; 7 (4): 216-24. Available from: http://www.ncbi. nlm.nih.gov/pubmed/25126373.

19. Hartley D. Rural health disparities, population health, and rural culture. American Journal Public Health. 2004 [cited October 2016]; 94 (10): 1675-8. Available from: http://www.ncbi.nlm.nih.gov/pubmed/ 15451729. 
20. Dégardin K, Roggo Y, Margot P. Forensic intelligence for medicine anti-counterfeiting. Forensic Scencei International journal. 2015 [cited November 2016]; 248: 15-32. Available from: https://www.ncbi.nlm. nih.gov/pubmed/25576676.

21. Ian CD. Systematic reviews. British Medical Journal Publishing Group; 1995.

22. United Nations Development Programme. Human development reports. United Nations Development Programme. 2016 [cited September 2016]. Available from : http://hdr.undp.org/en/composite/HDI. Published 2016.

23. International Medical Product Anticounterfeiting Taskforce (IMPACT): an update on estimates. International Medical Product Anticounterfeiting Taskforce. 2006 [cited December 2016]. Available from: http://apps.who.int/medicinedocs/en/d/Js20967en/

24. Hosseini SAR, Darbooy S, Tehrani Banihashemi SA, Naseri SM, Dinarvand R. Counterfeit medicines: Report of a cross-sectional retrospective study in Iran. Public Health Journal Iran. 2011; 125 (3): 16571.

25. Ames J, Souza DZ. Falsificação de medicamentos no Brasil. Review Saude Publica Journal. 2012 [cited November 2016]; 46 (1): 154-9. Available from: http://www.scielo.br/scielo.php?pid=S003489 $102012000100019 \&$ script $=$ sci_arttext $\&$ tlng $=$ en

26. Japan Medicine Manufacture Medicines (JPMA). Countermeasures against counterfeit medicines. Japan Medicine Manufacture Medicines. 2015 [cited Decmeber 2016]. Available from: http://www. jpma.or.jp/english/globalhealth/fake_measures/about_fake_measures.html

27. Pfizer. A serious threat to patient safety. Counterfeit medicines. Pfizer global security 2007 [cited November 2016]. Available from : http://www.pfizer.com/files/products/CounterfeitBrochure.pdf.

28. US Food and Drug Administration [Homepage on Internet]. Counterfeit medicines. Official website of US Food and Drug Administration 2016 [cited November 2016]. Available from : http://www.fda.gov/Drugs/ResourcesForYou/Consumers/BuyingUsing MedicineSafely/CounterfeitMedicine/

29. Punjab. Fake medicine: Unofficial death toll reaches 112 - The Express Tribune. Express Tribune. 2012 [cited September 2016]: 1. Available from : https://tribune.com.pk/story/328886/fake-medicine-unofficialdeath-toll-reaches-111/.

30. Nablus M. Palestinian police continue seizure of expired and counterfeit cosmetics, drugs and detergents. Maan News Agency. 2009 [cited September 2016]: 2. Available from: http://www.maannews.com/ Content. aspx?id=209799.

31. Zofeen I. Unregulated drug market has deadly impact in Pakistan I Inter Press Service. Interpress service [cited December 2016]. Available from : http://www.ipsnews.net/2012/12/unregulated-drug-market-has-deadly-impact-in-pakistan/.

32. International Institute of Study Agains Counterfeit Medicine (IRACM). 13 held in PIC drugs scandal Iran. 2012 [cited December 2016]. Available from : http://www.iracm.com/en/2012/03/13-held-in-picdrugs-scandal/.

33. Milissa M. Media reports on medicine quality: Focusing on USAID-assisted countries. United States Agency for International Development. 2013 [cited November 2016]. Available from: http://
www.usp.org/sites/default/files/usp_pdf/EN/PQM/media_reports2013-august.pdf.

34. Sauwakon R, Souly P. The state of medicine quality in the Mekong subregion in the 2000s and the challenges ahead. Institut de Recherche sur l'Asie du Sud-Est Contemporaine Study Institute on Contemporary Southeast Asia. 2015 [cited November 2016]. Available from : http://www.irasec.com/ouvrage115.

35. Badan Pengawas Obat dan Makanan. Laporan tahun 2015. Jakarta: Badan Pengawas Obat dan Makanan; 2015 [cited September 2016]. Available from : http://www.pom.go.id/new/index.php/browse/laporan_tahunan/20-04-2007/20-04-2017/1. Published 2015.

36. Daly MC, Duncan GJ, McDonough P, Williams DR. Optimal indicators of socioeconomic status for health study. America Journale Public Health. 2002 [cited November 2016]; 92 (7): 1151-7. Available from : http://www.ncbi.nlm.nih.gov/pubmed/12084700.

37. Food and Drugs Administration. Drug supply chain integrity - Issues letters to doctors who may have purchased counterfeit or unapproved prescription drugs. US Food and Drugs Administration. [2016] [cited November 2016]. Available from: https://www.fda.gov/Drugs/ DrugSafety/DrugIntegrityandSupplyChainSecurity/ucm439169.htm.

38. Catarina F. Country report: The healthcare market in Japan. PM Group Worldwide Limited; 2012 [cited November 2016]. Available from : http://www.pmlive.com/pharma_intelligence/country_report_the_healt hcare_market_in_japan_379354.

39. John PG, John P, Geoffrey R. Medicines medicines. London: John Wiley and sons Ltd; 2012.

40. Bankole S. Piracy and counterfeiting: Gatt trips and developing countries: International economic development law. Medicines Medicines. New York: Springer publisher; 1997.

41. Buckley GJ, Gostin LO. The effects of falsified and substandard drugs. USA: National Academies Press (US); 2013 [cited September 2016]. Available from : https://www.ncbi.nlm.nih.gov/books/NBK202526/.

42. Albert L PW. Counterfeit medicines?: Policy, economics, and countermeasures. United Kingdom: ILM Publications; 2012.

43. Bansal D, Malla S, Gudala K, Tiwari P. Anti-counterfeit technologies: a medicine industry perspective. Science Medicines journal. 2013 [cited October 2016)]; 81 (1): 1-13. Available from: https://www.ncbi. nlm.nih.gov/pmc/articles/PMC3617666/.

44. Royal Medicines Society of Great Britain. Counterfeit medicines advice for healthcare professionals: Guidance for pharmacist and dispensing Doctors. United Kingdom: Medicine and Healthcare Product Agency; 2009 [cited September 2016]. Available from: https://www.fip.org/ files/fip/counterfeit/national/UKCounterfeitadvice209.pdf

45. Gibson L. Drug regulators study global treaty to tackle counterfeit drugs. British Medical Journal. 2004 [cited November 2016]; 328 (7438). Available from: http://www.bmj.com/content/328/7438/ 486.4 .

46. International Medical Product Anti-Counterfeiting Taskforce. Counterfeit medicines: an update on estimates. World Health Organization. (cited November 2016) Available from: http:// www.who.int/medicines/services/counterfeit/impact/TheNewEstimates Counterfeit.pdf.

47. Morris J, Stevens P. Counterfeit medicines in less developed countries Problems and solutions about International Policy Network. In: 
Kesmas: National Public Health Journal, 2017; 11 (4): 153-162

International Policy Network.; 2006 [cited November 2016]: 1-9.. Available from: http://zuckermanfellows.harvard.edu/index.php/content/download/70550/1255010/version/1/file/Morris_Stevens.pdf

48. International Institute of StudyAgains Counterfeit Medicine (IRACM).
Prevention against global trafficking of counterfeit drugs. International Institute of StudyAgains Counterfeit Medicine. [cited December 2016]. Available from: http:// www.iracm.com/en/commitment-and-strategy/prevention/. 